\title{
Trauma in Elderly People Attended by a Mobile Emergency Service
}

Kennia Sibelly Marques de Abrantes 1,3 ,

Tarciana Nobre de Menezes ${ }^{2}$, Maria do Carmo Andrade Duarte de Farias ${ }^{1}$, Geofabio Sucupira Casimiro ${ }^{1}$, Arieli Rodrigues Nóbrega Videres ${ }^{1}$, Luiz Carlos de Abreu $^{3}$

Introduction: The process of aging causes bio-psychosocial changes, that commonly, make the elderly more likely to be affected by chronic diseases and disorders due to external causes.

Objective: Analize the occurrence of trauma and demographic characteristics of elderly people attended by a mobile emergency service.

Method: This is a cross-sectional study conducted in the city of Sousa, in northeast region of Brazil, using data from 190 records of elderly victims of trauma attended by the MES from January $1^{\text {St }}$ to December $31^{\text {St }}$ of 2011 . The Pearson's chi-square test $(x 2)$ or Fisher's exact test with Freeman-Halton extension, were used to observe possible associations between variables. A significance level of $\alpha<5 \%$ was considered.

Results: From the total of 190 elderly, 51.1\% were male, aged between 60 and 104 years, mean age of 75.3 years (SD 10.44 years) and median of 74.0 years. Regarding the occurrence of trauma, 91.6\% occurred in urban areas, $35.8 \%$ in the morning, $46.3 \%$ at weekend and $42.1 \%$ in the months from May to August. Falls stood out with $65.3 \%$ of cases and $87.9 \%$ had no alcohol on their breath during first-aid care. Among the injuries, wounds were predominant (62.3\%) and $87.4 \%$ were referred to hospital. A significant association was observed between the presence of alcohol on the breath and sex $(p<0.001)$ and age group $(p=0.004)$ and between trauma mechanism and sex $(p<0.001)$. Higher susceptibility was observed among males in the most advanced age group. Among the types of trauma, falls occurred mainly among women and traffic accidents among men. The presence of alcohol on the breath was verified especially among men and the majority of them were referred to hospitals. 
Conclusion: Knowledge of the characteristics of the demographics and occurrences of trauma in elderly people is necessary for the early identification of those individuals more exposed to this risk. Thus, it is considered that this research was relevant to characterize the elderly people requiring first-aid assistance and the occurrences of trauma, furthermore it is hoped that educational measures should be implemented in the community in order to prevent such traumas.

\section{Keywords}

Elderly. Mobile First.

Aid Service. Emergency Care.

\section{Introduction}

The aging process causes biopsychosocial changes, which commonly make the elderly people prone tochronic non-communicable diseases and hazards due to external causes; established by the World Health Organization (WHO) as a category to refer to the results of assaults and accidents, traumas and injuries [1].

In recent years the prevalence of trauma has increased significantly among the elderly population, which may be related to the adoption of a healthier and more active lifestyle, leading to greater exposure to external accidents [2]. Trauma currently constitutes the fifth leading cause of death in the elderly, thus, aging directly influences the increase in trauma related morbidity and mortality rates [3].

In the elderly, trauma presents itself as more critical by more often requiring hospitalization and for longer periods, due to the reduced capacity for recovery in this population. As a result, more resources are expended compared to those of other age groups; made up of direct costs, including diagnosis and rehabilitation costs throughout treatment and indirect costs which are related to the impact of the problem on individuals other than the patient [4].

Trauma is considered as an injury arising from accidental, self-imposed or violent force, and can affect several systems, which necessitates immediate attention in order to avoid the loss of a limbor life [5].
A retrospective study conducted in the state of Virginia, United States, consisting of 139 patients, including the elderly (aged over 65 years) and younger adults (16-64 years) showed that mortality was twice as high in the elderly compared to the younger adults, despite similar wound intensity [6]. In Brazil, in the year 2000, there were over thirteen thousand deaths from external causes in the elderly, representing $11.4 \%$ of total deaths from these causes [7]. In the middle of the XXI century, the elderly accounted for about $40 \%$ of trauma victims [8].

Thus, the objective of this study was to analize the occurrence of trauma and demographic characteristics of elderly people attended by a mobile emergency service.

\section{Method}

This study is characterized as being cross-sectional with a quantitative approach, carried out on the Mobile First-Aid Service of the municipality of Sousa - Paraíba in the northeast of Brazil. This location was chosen because it is considered as a reference point of the emergency service in the city and surrounding municipalities. Information was collected from records of all trauma occurrences with elderly victims who were aided by the Mobile Emergency Service during the period of January $1^{\text {st }}$ to December $31^{\text {st }}$ of 2011, as well as the forms were filled in by the Technicians for Medical Regulations (TMR). 
In the study were included the records of occurrence for individuals of both sexes, aged over 60 years, permanent residents in Sousa, who were victims of some type of trauma that occurred in the city of Sousa (urban and rural) and served by the Mobile Emergency Service team based in the city.

The data was collected in January 2012 from the records of the occurrences of trauma with elderly victims, as well as the forms filled in by the Technicians for Medical Regulations (TMR).

To collect the data, a specific form was used, which had been prepared following the model of the occurrence form, taking into consideration the demographic information of the elderly such as gender (female, male) and age group (60 to 69 years, 70 to 79 years and 80 years or over); as well as information on the occurrence of the trauma such as: time period (morning, 06:00-11:59, afternoon, 12:00-17:59 and night/early morning, 18:00-05:59), location (urban area; rural area), day of the week (Monday and Tuesday; Wednesday and Thursday; Friday, Saturday and Sunday), month (January to April; May to August; September to December), mechanism of trauma(falls, traffic and other accidents, highlighting assault, stab wounds and dog bites), principal injuries (wounds - including any kind of cut or abrasion; osteoarticular injuries - including head trauma, fractures, dislocations and sprains; bleeding - nasal, otorrhagia, hematoma and others - swelling and bruising).

The categories for the different mechanisms of trauma were extracted from Chapter $X X$ of the CID-10: External causes of morbidity and mortality (V01-Y98) which include falls (W00-W19), traffic accidents (V01-V99) and others, highlighting assault (X85-Y09), stab wounds (X99) and dog bites (W54) [9].

In cases where the victim had more than one group of injuries, we used the criterion of priority treatment according to the severity of the injury. Cases where insufficient information was available were excluded from the analysis.
Information on the presence or absence of alcohol on the breath (observed by the professionals during assessment and recorded on the occurrence form) and the referral of patients (released after treatment, died at the location, refused care and referred to hospital) was also collected.

The database was compiled using the software Statistical Package for the Social Sciences - SPSS, version 17.0, for Windows. The association between the characteristics of occurrence and sex and age group was assessed using Pearson's chi-square test $(\chi 2)$, or Fisher's exact test with the Freeman-Halton extension when appropriated. The level of significance was set at $<5 \%$.

This research project was approved by the Committee for Ethics in Research (CEP) from the Paraíba State University (UEPB), protocol number 0763.0.133.000-11, on the $15^{\text {th }}$ of December of 2011.

\section{Results}

In the period analyzed 190 elderly, who were victims of various traumas, received help from the Mobile First-Aid Service in the municipality of Sousa-PB. The age of the elderly ranged from 60 to 104 years, with a mean of 75.3 years (SD $=10.4$ years) and $a$ median of 74.0 years.

Of the elderly who suffered a trauma, the majority was male (51.1\%). Regarding age groups, the majority was 80 years or over (34.7\%) (74.2\% female and $25.8 \%$ male). Of the total, $33.2 \%$ were aged 60 to 69 years $(25.4 \%$ female and $74.6 \%$ male) and $32.1 \%$ were 70 to 79 years $(45.9 \%$ female and $54.1 \%$ male).

Table 1 presents the distribution of the elderly, according to the characteristics of the occurrence of trauma and sex. The table demonstrates that regarding location, the majority of occurrences, both among men and women, occurred in urban areas (89.7\% and $93.5 \%$, respectively). No statistically significant association was observed 
Table 1. Distribution of the elderly, according to the characteristics of the occurrence of the trauma and sex. Sousa/PB, 2011.

\begin{tabular}{|c|c|c|c|c|c|}
\hline \multirow{3}{*}{$\begin{array}{l}\text { Characteristics of } \\
\text { Occurrence }\end{array}$} & \multicolumn{4}{|c|}{ Sex } & \multirow{3}{*}{$p$} \\
\hline & \multicolumn{2}{|c|}{ Feminine } & \multicolumn{2}{|c|}{ Masculine } & \\
\hline & $n$ & $\%$ & $n$ & $\%$ & \\
\hline \multicolumn{6}{|l|}{ Location } \\
\hline Urban area & 87 & 93.5 & 87 & 89.7 & \multirow{2}{*}{0.338} \\
\hline Rural area & 6 & 6.5 & 10 & 10.3 & \\
\hline \multicolumn{6}{|l|}{ Period } \\
\hline Morning & 34 & 36.6 & 34 & 35.1 & \multirow{3}{*}{0.655} \\
\hline Afternoon & 28 & 30.1 & 35 & 36.1 & \\
\hline Night & 31 & 33.3 & 28 & 28.9 & \\
\hline \multicolumn{6}{|l|}{ Day of the week } \\
\hline Friday/Saturday/Sunday & 41 & 44.1 & 47 & 48.5 & \multirow{3}{*}{0.504} \\
\hline Monday/Tuesday & 25 & 26.9 & 29 & 29.9 & \\
\hline Wednesday/Thursday & 27 & 29.0 & 21 & 21.6 & \\
\hline \multicolumn{6}{|l|}{ Month } \\
\hline January to April & 28 & 30.1 & 22 & 22.7 & \multirow{3}{*}{0.472} \\
\hline May to August & 36 & 38.7 & 44 & 45.4 & \\
\hline $\begin{array}{l}\text { September to } \\
\text { December }\end{array}$ & 29 & 31.2 & 31 & 32.0 & \\
\hline \multicolumn{6}{|c|}{ Presence of alcohol on the breath * } \\
\hline Yes & 2 & 2.2 & 21 & 21.6 & \multirow{2}{*}{$\begin{array}{c}< \\
0.001\end{array}$} \\
\hline No & 91 & 97.8 & 76 & 78.4 & \\
\hline \multicolumn{6}{|l|}{ Mechanism of trauma } \\
\hline Falls & 72 & 77.4 & 52 & 53.6 & \multirow{3}{*}{$\begin{array}{c}< \\
0.001\end{array}$} \\
\hline Traffic accidents & 10 & 10.8 & 33 & 34.0 & \\
\hline Other & 11 & 11.8 & 12 & 12.4 & \\
\hline \multicolumn{6}{|l|}{ Principal injuries** } \\
\hline Wounds & 33 & 53.2 & 53 & 69.7 & \multirow{4}{*}{0.236} \\
\hline Osteoarticular lesions & 16 & 25.8 & 12 & 15.8 & \\
\hline Bleeding & 7 & 11.3 & 7 & 9.2 & \\
\hline Other & 6 & 9.7 & 4 & 5.3 & \\
\hline \multicolumn{6}{|l|}{ Referral** } \\
\hline Released after care & 11 & 11.8 & 8 & 8.2 & \multirow{4}{*}{0.795} \\
\hline Died at the location & 1 & 1.1 & 1 & 1.0 & \\
\hline Refused care & 1 & 1,1 & 2 & 2.1 & \\
\hline Referred to hospital & 80 & 86.0 & 86 & 88.7 & \\
\hline \multicolumn{6}{|c|}{$\begin{array}{l}\text { Source: Research Data (SAMU -Medical/attendance } \\
\text { regulation form, 2011). } \\
\text { * Fisher's exact test performed. } \\
\text { * Fisher's exact test with Freeman-Halton extension } \\
\text { performed. }\end{array}$} \\
\hline
\end{tabular}

between the occurrence of the trauma site and $\operatorname{sex}(p=0.338)$.

With respect to the time period of the occurrence, the proportions between men and women were similar; among women the highest number of occurrences was in the morning (36.6\%) and among men in the afternoon (36.1\%). No statistically significant association was observed between the time period of the trauma occurrence and sex $(p=0.655)$.

Regarding the day of the occurrence, Friday, Saturday and Sunday were prominent in both sexes (48.5\% and $44.1 \%$ for males and females respectively). There was no statistically significant association between the day of occurrence and sex ( $p=$ 0.504).

With regard to the month of occurrence of the trauma, in both sexes, the highest proportion of injuries occurred in the months from May to August, corresponding to $45.4 \%$ in elderly males and $38.7 \%$ in elderly females. There was no statistically significant association between the month of occurrence and sex $(p=0.472)$.

As for the presence of alcohol on the breath, for both men and women there was a predominance of absence of alcohol on the breath $(78.4 \%$ and $97.8 \%$, respectively), with a statistically significant association between the presence of alcohol on the breath and sex ( $p<0.001)$.

When considering the mechanism of the trauma that occurred, it was observed that falls (65.3\%) and traffic accidents (22.6\%) were the most prevalent. Among the elderly women, falls accounted for $77.4 \%$ of trauma cases and in the men $53.6 \%$. Traffic accidents among men accounted for $34.0 \%$ and among women $10.8 \%$. A statistically significant association was found between the mechanism of injury and sex $(p<0.001)$.

As to the principal injuries suffered by the elderly, the greatest proportion were wounds among both men $(69.7 \%)$ and women (53.2\%), followed by osteoarticular lesions $(15.8 \%$ and $25.8 \%$, respecti- 
vely). There was no statistically significant association between principal injuries and sex $(p=0.236)$.

In relation to the referral of victims, it was observed that the majority of both men and women were taken to hospital $(88.7 \%$ and $86.0 \%$, respectively) after the occurrence of the trauma. There was no statistically significant association between referral and sex $(p=0.795)$.

Table 2 presents information on the distribution of the elderly participants according to the cha-

Table 2. Distribution of the elderly, according to the characteristics of the occurrence of the trauma and age group. Sousa/PB, 2011.

\begin{tabular}{|c|c|c|c|c|c|c|c|}
\hline \multirow{3}{*}{$\begin{array}{c}\text { Characteristics of } \\
\text { Occurrence }\end{array}$} & \multicolumn{6}{|c|}{ Age Group } & \multirow{3}{*}{$p$} \\
\hline & \multicolumn{2}{|c|}{60 to 69 years } & \multicolumn{2}{|c|}{70 to 79 years } & \multicolumn{2}{|c|}{80 years or over } & \\
\hline & $\mathrm{n}$ & $\%$ & $\mathrm{~N}$ & $\%$ & $\mathrm{n}$ & $\%$ & \\
\hline \multicolumn{8}{|l|}{ Location } \\
\hline Urban area & 57 & 90.5 & 56 & 91.8 & 61 & 92.4 & \multirow{2}{*}{0.921} \\
\hline Rural area & 6 & 9.5 & 5 & 8.2 & 5 & 7.6 & \\
\hline \multicolumn{8}{|l|}{ Period } \\
\hline Morning & 24 & 38.1 & 20 & 32.8 & 24 & 36.4 & \multirow{3}{*}{0.972} \\
\hline Afternoon & 21 & 33.3 & 21 & 34.4 & 21 & 31.8 & \\
\hline Night & 18 & 28.6 & 20 & 32.8 & 21 & 31.8 & \\
\hline \multicolumn{8}{|l|}{ Day of the week } \\
\hline Friday/Saturday/Sunday & 28 & 44.4 & 31 & 50.8 & 29 & 43.9 & \multirow{3}{*}{0.605} \\
\hline Monday/Tuesday & 16 & 25.4 & 19 & 31.1 & 19 & 28.8 & \\
\hline Wednesday/Thursday & 19 & 30.2 & 11 & 18.0 & 18 & 27.3 & \\
\hline \multicolumn{8}{|l|}{ Month } \\
\hline January to April & 13 & 20.6 & 16 & 26.2 & 21 & 31.8 & \multirow{3}{*}{0.126} \\
\hline May to August & 25 & 39.7 & 23 & 37.7 & 32 & 48.5 & \\
\hline September to December & 25 & 39.7 & 22 & 36.1 & 13 & 19.7 & \\
\hline \multicolumn{8}{|c|}{ Presence of alcohol on the breath ** } \\
\hline Yes & 16 & 25.4 & 5 & 8.2 & 2 & 3.0 & \multirow{2}{*}{0.004} \\
\hline No & 47 & 74.6 & 56 & 91.8 & 64 & 97.0 & \\
\hline \multicolumn{8}{|l|}{ Mechanism of trauma } \\
\hline Falls & 33 & 52.4 & 43 & 70.5 & 48 & 72.7 & \multirow{3}{*}{0.065} \\
\hline Traffic accidents & 22 & 34.9 & 11 & 18.0 & 10 & 15.2 & \\
\hline Other & 8 & 12.7 & 7 & 11.5 & 8 & 12.1 & \\
\hline \multicolumn{8}{|l|}{ Principal injuries** } \\
\hline Wounds & 32 & 64.0 & 26 & 61.9 & 28 & 60.9 & \multirow{4}{*}{0.994} \\
\hline Osteoarticular lesions & 9 & 18.0 & 9 & 21.4 & 10 & 21.7 & \\
\hline Bleeding & 6 & 12.0 & 4 & 9.5 & 4 & 8.7 & \\
\hline Other & 3 & 6.0 & 3 & 7.1 & 4 & 8.7 & \\
\hline \multicolumn{8}{|l|}{ Referral** } \\
\hline Released after care & 6 & 9.5 & 7 & 11.5 & 6 & 9.1 & \multirow{4}{*}{0.888} \\
\hline Died at the location & 1 & 1.6 & 1 & 1.6 & 0 & 0 & \\
\hline Refused care & 1 & 1.6 & 0 & 0 & 2 & 3.0 & \\
\hline Referred to hospital & 55 & 87 & 53 & 86.9 & 58 & 87.9 & \\
\hline
\end{tabular}


racteristics of the occurrence of the trauma and age group. Regarding the place of occurrence of the trauma suffered by the elderly included in this study, the urban area was predominant in all age groups, accounting for 90.5\% (60-69 years), 91.8\% (70-79 years) and $92.4 \%$ (80 or over). There was no statistical significance between the accident location and age group ( $p=0.921)$.

Related the hours when the trauma occurred, the daytime was the most prevalent in all age groups. In the age groups 60-69 years and 80 years or over, the morning period was the most common with $38.1 \%$ and $36.4 \%$, respectively.In the $70-79$ year age group, the afternoon periodwas more frequent with $34.4 \%$. No statistically significant association was found between the time of day when the trauma occurred and age group ( $p=0.972$ ).

In Table 2, the distribution of the elderly according to the day of the week on which the trauma occurred and the age group are presented.Friday, Saturday and Sunday were predominant in all age groups, being $50.8 \%$ among those aged 70-79 years; $44.4 \%$ among those aged 60-69 years and $43.9 \%$ among those aged 80 or more. There was no statistically significant association between the day of occurrence and age group $(p=0.605)$.

With regard to the month of the occurrence of the trauma, in all age groups the months from May to August predominated (48.5\% among those aged 80 years or over, $39.7 \%$ for $60-69$ years and $37.7 \%$ for 70-79 years).There was no statistically significant association between the month of occurrence and the age group ( $p=0.126$ ).

Regarding the presence of alcohol on the breath, it was found that the majority of the elderly in all age groups presented no alcohol on the breath, being $97.0 \%$ among those aged 80 years or over, $91.8 \%$ for 70 to 79 years and $74.6 \%$ among those aged 60 to 69 years. A statistically significant association was observed between the presence of alcohol on the breath and age group ( $p=0.004)$.
In relation to the mechanism of injury in all age groups, falls and traffic accidents are highlighted with falls being the most prevalent among the elderly aged 80 and over (72.7\%) and traffic accidents among those aged 60-69 years (34.9\%). No statistically significant association was observed between the mechanism of injury and age group ( $p=0.065)$.

As for the principal injuries found among the elderly, in all age groups wounds were the most prevalent, particularly in the elderly aged 60-69 (64\%) and osteoarticular lesions among those aged 80 years or older (21.7\%).There was no statistically significant association between the principal injuries and age group ( $p=0.994$ ).

Considering the referral of the elderly in this stu$\mathrm{dy}$, emphasis is given to the significant proportion of victims sent to hospital after the occurrence of the trauma, regardless of age group (87.9\% of those aged 80 years or over; $87.3 \%$ of those 60 to 69 years and $86.9 \%$ of those 70 to 79 years). No statistically significant association was found between referral and age group ( $p=0.888)$.

\section{Discussion}

Brazil is increasingly becoming a country of white hair and this process brings consequences for Brazilian society, as the rising elderly population necessities urban reorganization and adequate public and private services to accommodate the characteristics of this population. In Brazil, aging is an urban phenomenon, the result of the migration of the population around 1960 to meet the industrialization process of the country [10].

Faced with this changing population profile, the plight of elderly trauma victims and the need for preventive measures against this grievance are highlighted. The subject of elderly care involves issues such as the more frequent need for hospitalization, longer periods of hospitalization and rehabilitation and the greater cost to the health system [11]. 
Thus, by analyzing the characteristics of the demographics and occurrences of trauma in elderly victims attended by the Mobile First-Aid Service in a Brazilian Northeast city, we sought to promote discussions on access to this service and ways to manage care in the elderly, specifically victims of trauma. This information is very important as well as the observation of the particularities and specificities of trauma in this population as they could be influential in strengthening promotion and prevention in this field

The occurrence of trauma has great impact on the health of the elderly, given that elderly subjects have small functional reserves of various organs and systems [12], which may be unable to respond to the increased physiological demands imposed by this negative event. Advanced age leaves individuals more physically and mentally fragile, very often dependent and therefore more vulnerable, which further increases the significance of the trauma [13].

In this research, during the period analyzed, a slight predominance of elderly males was found among those who suffered trauma. This predominance was observed in a study performed in Londrina/PR, where $59.5 \%$ of the elderly who suffered trauma were male [8]. Studies conducted in the Northeast [14], Southeast [15] and South [4] of Brazil, as well as in the United States [16] and Poland [17] found a higher prevalence of men affected by trauma, which may be due to the fact that men are more exposed as they circulate more frequently in the urban area, and participate more in the labor market [18].

As for the age group, the results of this research demonstrated a prevalence of trauma among the oldest age group and, regarding sex, the highest proportion of women were in the 80 or over age group, unlike the men, where the proportion was higher in the group from 60 to 69 years. This higher percentage of women aged 80 or over is due to the higher life expectancy of women, who present lower alcohol consumption and smoking, more often make use of the health services and lead a more active lifestyle, in addition to the biological and genetic aspects [19].

Studies evaluating the occurrence of trauma in the elderly have found high proportions of both younger elderly $[13,20]$, and older elderly individuals [21, 22] affected.

The aging process encompasses increased incidences of several diseases, either through biological processes or through long periods of exposure to pathogens. Moreover, together with increasing age, arise more restrictions, less dexterity and greater difficulty in performing activities of daily living [23].

Given the increased susceptibility of the elderly, especially the oldest age group, to be affected by trauma it is necessary that preventive actions are implemented which take into consideration the age related differences which exist even among the elderly them selves. This is justified by the projections of the World Health Organization (WHO), who estimate that in 2025, 1.2 billion people will be over 60 years old with those aged 80 years or over constituting the fastest growing age group [9].

Although some studies with the elderly have demonstrated the existence of an association between sex and age group and some characteristics of trauma occurrence such as location [24], time of day [25], day of the week [20], monthn [26], type of injury [27] and referral [18], in this study, these associations were not observed. However, we must consider the high proportion of elderly affected by trauma in urban areas, with the primary injury being wounds and the majority being referred to hospital.

The predominance of the urban area as the location of trauma occurrence among the elderly of both sexes was expected given that associated with the intense growth of the elderly population, there has been a rapid process of urban concentration in Brazil, due to a large migratory movement, contradicting the hypothesis that in developing countries the elderly population is predominantly located in rural areas [28]. 
According to the data from the IBGE 2010 Brazilian census, $84.35 \%$ of the population resided in urban areas and $15.65 \%$ in rural areas.In the city of Sousa, the majority (78.84\%) of the population lived in urban areas [29], which may explain the higher percentage of traumas attended toin this study.In the urban area elderly individuals have a more active pace of life due to the dynamics of postmodern society, which favors a variety of interpersonal relationships and human/environment relationships, predisposing the elderly to traumatic situations, principally because they are more vulnerable [30].

The high proportion of elderly subjects who suffered injuries and needed to be referred to hospital due to the complexity of the trauma is a concern, given the vulnerability of this population. Trauma in the elderly is a major cause of injury, disability and hospitalization, as the damage usually reaches other organs besides those directly affected by the initial injury [5].

Thus, it is possible to identify the fragility of the elderly, since the majority required referral to hospital as a result of the trauma. These data are consistent with research conducted in Londrina - PR, where $84 \%$ of the elderly required referral to a center where the complex effects of the trauma could be addressed; 7\% were released, without requiring medical attention and $2 \%$ died at the location or were already dead when the medical services arrived [18].

Data from this study demonstrated that the presence of alcohol on the breath was associated with both sex and age group, with the highest proportion of the elderly presenting no alcohol on the breath. The men presented a greater proportion of the presence of alcohol on the breath, which can be attributed mainly to cultural aspects rather than biological factors31. In a study conducted with victims of motorcycle accidents in 1998 and 2010, it was pointed out that only victims aged 60 or over demonstrated a percentage increase in the percep- tion of alcohol on the breath, increasing from zero to $3.2 \%$ in the respective years [32].

As a result, it is both necessary and justifiable to verify the presence of alcohol on the breath in trauma victims of all ages, especially males, since alcohol abuse is evident in the modern world [32].

In this study, the younger group of the elderly (60-69 years) had a higher proportion of the presence of alcohol on the breath. Octogenarians and older (80 or over) presented the greatest proportion of the absence of alcohol on the breath. The use of alcohol prior to the trauma event is an important aspect to be verified, especially among the "younger elderly". The abusive and/or inappropriate use of this substance can have serious consequences, among which is the occurrence of injuries from external causes, particularly trauma [33].

The limited number of studies focusing on the frequency of alcohol consumption among the elderly in Brazil hinders further discussion on this topic. The available data on the role of alcohol in the origin of trauma in elderly individuals are derived mainly from retrospective analyzes, probably due to the difficulties inherent in conducting prospective studies [34].

A survey conducted in Pelotas - RS, on the consumption of alcohol, concluded that there was more abuse in the elderly [35]. Research shows that problems related to alcohol may be present in 1-10\% of the elderly living in the community [36].

It is worth mentioning an analysis conducted by the Ministry of Health, on patterns of alcohol consumption in the Brazilian population, in which it was found that the elderly reported drinking more frequently at home than in bars. On one hand, as a result, the elderly are exposed to less traffic accidents, but on the other hand, they become vulnerable to other consequences of drinking such as falls, which are more likely to occur at home [35].

Based on the analysis presented, it was noted in a review of 16 population studies, that men 
frequently drank for longer periods and in larger quantities, had higher rates of episodes of abuse and consequences associated with drinking than women [37].

In this study the mechanism of trauma was associated only with sex, despite the high proportion of falls in all age groups. Falls were the most prevalent mechanism of trauma, followed by traffic accidents; results similar to those observed in other studies [5, 18].

It was verified in this study and in another held in the same location [38] that women constituted the most affected group by the falling. In a two years segment research of a 1,667 elderly cohort that live in the community, researchers found that being female increase about twice the chances of falling significantly [39].

There are several factors that explain the higher incidence of falls among elderly women, although the mechanisms are not fully understood; the greater fragility of females compared to males, increased exposure to domestic activities, older age, a higher prevalence of chronic diseases such as osteoporosis, increased use of medication, less fat-free mass and muscle strength [39].

Falls in the elderly are a major public health problem, due to their high incidence, the consequent health complications and the high social and economic costs from the resulting injuries [39].

Traffic accidents were the second most prevalent mechanism of injury among the elderly, with men presenting a greater proportion than women. Such information may be related to a greater functional independence which enables elderly males to perform various activities which consequently expose them to traffic accidents [3].

It is hoped that the data obtained in this study will contribute to the area of public health, as well as other areas of study focused on the elderly population. We draw attention to the importance of these results, given that trauma is a major cause of injury, disability and hospitalization and the impact has considerable importance in the lives of the elderly, high economic and social costs and the burden placed on the health services [5].

This study highlights the importance of developing new research aimed at disseminating knowledge on trauma in the elderly, in order to minimize as much as possible, the impact of this event on the functional capacity and quality of life of the elderly and thereby contribute to a safe and healthy aging period. Moreover, it is important to stress the difficulty in collecting data with respect to filling in the occurrence forms, as well as the difficulty in finding research studies similar to this one as the majority are held in large centers which present different realities, and the fact that many studies do not work specifically with the elderly population.

Finally, it was observed that the main cause of trauma differ and more advanced age group; major trauma causes show any difference, focusing between falling, especially among women and traffic accidents among men. It was found also significant association between the presence of alcohol on the breath with the gender and age and mechanism of trauma to sex. 


\section{References}

1. Minayo MCS. Violência contra idosos: relevância para um velho problema. Cad. saúde pública. 2003;19(3):783-791.DOI: 10.1590/S0102-311X2003000300010

2. Katz M, Okuma MAA, Santos ALG, Guglielmetti CLB. Epidemiologia das lesões traumáticas de alta energia em idosos. Acta ortop. bras.2008; 16(5): 279-283. DOI: 10.1590/S141378522008000500005

3. Lima RS, Campos MLP. Perfil do idoso vítima de trauma atendido em uma Unidade de Urgência e Emergência. Rev. Esc. Enferm. USP. 2011; 45(3): 659-664. DOI: 10.1590/S008062342011000300016

4. Souza RKT, Soares DFPP, Mathias TAF, Andrade OG, Santana RG. Idosos vítimas de acidentes de trânsito: aspectos epidemiológicos e impacto na sua vida cotidiana. Acta sci., Health sci. 2003; 25(1): 19-25. DOI:1010.4025/actascihealthsci. v25i1.2247

5. Campos JFS, Poletti NAA, Rodrigues CDS, Garcia TPR, Angelini JF, Dollinger APAV, Ribeiro RCHM, et al. Trauma em idosos atendidos no Pronto Atendimento da Emergência do Hospital de Base. Arq. ciênc. saúde. 2007; 14(4): 193-197.

6. Biazin DT. Avaliação da capacidade funcional pós-trauma em idosos [Tese]. São Paulo: Universidade de São Paulo; 2005.

7. Gawryszewski VP, Jorge MHP, Koizumi MS. Mortes e internações por causas externas entre os idosos no Brasil: o desafio de integrar a saúde coletiva e atenção individual. Rev. Assoc. Méd. Bras.2004; 50(1): 97-103. DOI: 10.1590/S010442302004000100044

8. Biazin DTRA, Rodrigues P. Perfil de idosos que sofreram trauma em Londrina - Paraná. Rev. Esc. Enferm. USP. 2009;43(3):602608. DOI: 10.1590/S0080-62342009000300015

9. Organização Mundial da Saúde. The world health report. Geneva: Organização Mundial da Saúde; 2001.

10. Veras RP. Terceira idade: gestão contemporânea em saúde. Rio de Janeiro: RelumeDumará; 2002.

11. Rodrigues J, CiosakSR. Idosos vítimas de trauma: análise de fatores de risco. Rev. Esc. Enferm. USP. 2012; 46(6): 1400-1405. DOI: 10.1590/S0080-62342012000600017

12. Mesquita GV, Lima MALTA, Santos AMR, Alves ELM, Brito JNPO, Martins MCC. Morbimortalidade em idosos por fratura proximal do fêmur. Texto \& contexto enferm. 2009; 18(1): 67-73. DOI: 10.1590/S0104-07072009000100008

13. Pinto TCA, Maciel SML, Xavier AFC, Pinto AKA, Cavalcanti AL. Morbidade por causas externas em idosos e sua relação com lesões maxilofaciais. PesqBrasOdontopedClín Integr. 2008; 8(2): 159-164. DOI: 10.4034/1519.0501.2008.0082.0005

14. Silva JJL, Lima AAAS, Melo IFS, Maia RCL, Pinheiro Filho TRC. Trauma facial: análise de 194 casos. Rev. bras. cir. plást. 2011; 26(1): 37-41. DOI: 10.1590/S1983-51752011000100009
15. Gawryszewski VP. A importância das quedas no mesmo nível entre idosos no Estado de São Paulo. Rev. Assoc. Med. Bras. 2010;56(2):162-167.

16. Malhotra S, Kasturi K, Abdelhak N, Paladino L, Sinert R. The accuracy of the olfactory sense in detecting alcohol intoxication in trauma patients. Emerg Med J. 2012; 30(11): 923-925. DOI: 10.1136/emermed-2012-201548

17. Skalska A, Wizner B, Piotrowicz K, Klich-Raczka A, Klimek E, Mossakowska $M$, et al. The prevalence of falls and their relation to visual and hearing impairments among a nation-wide cohort of older Poles. ExpGerontol. 2012; 20(12): 140-146. DOI: 10.1016/j.exger.2012.12.003

18. Silva FS, Oliveira SK, Moreno FN, Martins EAP. Trauma no idoso: casos atendidos por um Sistema de Atendimento de Urgência em Londrina, 2005. Com. Ciências Saúde. 2008; 19(3): 207-214.

19. Paschoal SMP, Salles RFN, Franco RP. Epidemiologia do Envelhecimento. $2^{\text {a }}$ ed. São Paulo: Atheneu; 2005.

20. Silveira R, Rodrigues RAP, Costa Júnior ML. Idosos que foram vítimas de acidentes de trânsito no município de Ribeirão PretoSP, em 1998. Rev. latinoam. enferm.2002; 10(6): 765-771. DOI: 10.1590/S0104-11692002000600003

21. Filgueiras MC, Santiago FR, Santiago HAR, Vieira LJES. Fraturas em idosos decorrentes de quedas registradas em hospital terciário de referência em traumatologia no ano de 2004. Rev. bras. promoç. saúde. 2007; 20(4): 226-232. DOI: 10.5020/18061230.2007.p226

22. Lojudice DC,Laprega MR, Rodrigues RAP, Rodrigues Júnior AL. Quedas de Idosos institucionalizados: ocorrência e fatores associados. Rev. bras. geriatr. gerontol.2010; 13(3): 403-412.

23. Ebert $\mathrm{MH}$. Doenças crônicas, fragilidade e características emocionais de idosos comunitários: estudo fibra Ivoti/RS [Dissertação]. Novo Hamburgo: Universidade Feevale; 2012.

24. Alba R. Prevalência de queda em idosos do meio rural assistidos por uma estratégia de saúde da família [Monografia]. Porto Alegre: Escola de Enfermagem da Universidade Federal do Rio Grande do Sul (UFRGS); 2011.

25. Álvares LM, Lima RC, Silva RA. Ocorrência de quedas em idosos residentes em instituições de longa permanência em Pelotas, Rio Grande do Sul, Brasil. Cad. saúde pública. 2010; 26(1): 3140. DOI: 10.1590/S0102-311X2010000100004

26. Riera R, Trevisani VFM, Ribeiro JPN. Osteoporose - a importância da prevenção de quedas. Rev. bras. reumatol. 2003;43(6):364368. DOI: 10.1590/S0482-5004200300600008

27. Gac HE, Marin PPL, Castro SH, Hoyl TM, Valenzuela EA. Caídas em adultos mayores institucionalizados: descripción y evaluación geriátrica. Rev. méd. Chile. 2003; 131(8): 887-894. DOI: $10.4067 /$ S0034-9887200300800008 
28. Justo A, Rosa CA, Nogueira FH. Queda como mecanismo de trauma mais frequente em idosos [Monografia]. Londrina: Instituto de Estudos Avançados de Pós-Graduação (ESAP); 2010.

29. Instituto Brasileiro de Geografia e Estatística [homepage na Internet]. Distribuição da população urbana e rural no Brasil, 2010. [Acesso em: 09 jul 2012]. Disponível em: <http://www. ibge.gov.br>.

30. Melo JMS, Abrantes KSM, Casimiro GS. Trauma no Idoso: perfil epidemiológico de vítimas socorridas pelo Serviço de Atendimento Móvel de Urgência (SAMU) no município de Sousa-PB [Monografia]. Cajazeiras: Universidade Federal de Campina Grande; 2010.

31. Wilsnack SC,Wilsnack RW. International gender and alcohol research: recent findings and future directions. Alcohol Research and Health. 2002; 26(4): 245-250.

32. Gabani FL. Motociclistas atendidos por Serviços de Atenção PréHospitalar em Londrina (PR): características dos acidentes e das vítimas em 1998 a 2010 [Dissertação]. Londrina: Universidade Estadual de Londrina; 2011.

33. Freitas EAM, Mendes ID, Oliveira LCM. Ingestão alcoólica em vítimas de causas externas atendidas em um hospital geral universitário. Rev. saúde pública.2008; 42(5): 813-821. DOI: 10.1590/S0034-8910200800500005

34. Barros E, Albuquerque GC, Pinheiro CTS. Exame Clínico: consulta rápida. $2^{a}$ ed. Porto Alegre: Artmed; 2004.

35. Ministério da Saúde. I Levantamento nacional sobre os padrões de consumo de álcool na população brasileira. Brasília, DF: Ministério da Saúde; 2007.

36. Almeida OP. Idosos atendidos em serviço de emergência de saúde mental: características demográficas e clínicas. Rev. bras. psiquiatr.1999; 21(1): 12-18. DOI: 10.1590/S151644461999000100005

37. Kerr-Corrêa F, Hegedus AM, Tucci AM, Trinca LA, Kerr-Pontes LRS, Floripes TF, et al. Differences in patterns of alcohol use between men and women in Botucatu, São Paulo. In: Obot I, Room R. Alcohol, gender and drinking problems a perspective from low and middle income countries.Genebra: World Health Organization; 2005.p.49-68.
38. Abrantes KSM, Menezes TN, Farias MCAD, Silva MIL, Rolim VE, Macedo Junior $\mathrm{H}$, et al. Caracterização das quedas em idosos socorridos pelo serviço de atendimento móvel de urgência. ABCS healthsci. 2013; 38(3): 126-132. DOI: 10.7322/abcshs. v38i3.17

39. Perracini M, Ramos LR. Fatores associados a quedas em uma coorte de idosos residentes no município de São Paulo. Rev. saúde pública.2002; 36(20): 709-716. DOI: 10.1590/S003489102002000700008

40. Freitas Júnior OS. Queda de idosos que motiva atendimento hospitalar de emergência pelo SUS em Uberlândia-MG: epidemiologia e consequências para a saúde [Dissertação]. Uberlândia: Universidade Federal de Uberlândia; 2006.

\section{Comment on this article:}

\section{(f) $[$ in $8+S$ P}

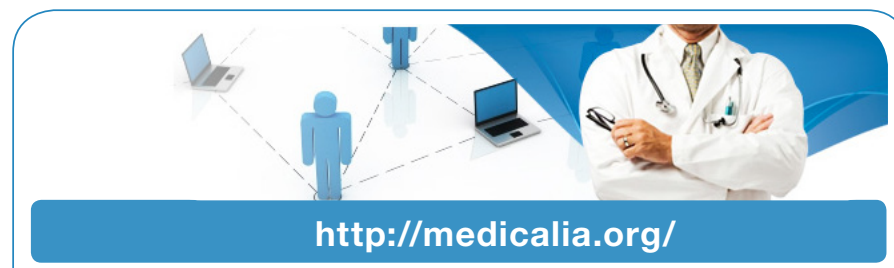

Where Doctors exchange clinical experiences, review their cases and share clinical knowledge. You can also access lots of medical publications for free. Join Now!

\section{Publish with iMedPub}

http://www.imed.pub

International Archives of Medicine is an open access journal publishing articles encompassing all aspects of medical science and clinical practice. IAM is considered a megajournal with independent sections on all areas of medicine. IAM is a really international journal with authors and board members from all around the world. The journal is widely indexed and classified Q1 in category Medicine. 